\title{
The Servant-Leader Model: Air Force Lawyers
}

\author{
Jaime Sampayo \\ Colorado Technical University
}

Kennedy Maranga

The purpose of this paper is to describe what the Air Force Judge Advocate General's Corps (AFJAGC) $(U S A F, 2018 c)$ has been, where it currently is, where it is headed, and how it should get there, in terms of leadership style for managing its lawyers. The goal is accomplished by developing a formal lawyer management model. Theoretically, a model may be developed to bring the AFJAGC into the 21st century. This paper is a snapshot analysis as to how Air Force lawyers operate from a servant-leader perspective and grow in their management styles and skills. This paper addresses the management of professionals' paradigm. Since there is very little on current literature on the management/leadership of lawyers, this paper may answer questions relating to managing lawyers and handling professionals in general. This should be beneficial to the military (the Air Force) and hopefully the legal industry as a whole.

\section{INTRODUCTION}

There is no known AFJAGC formal lawyer training model, although this has often been mentioned. Currently, there are approximately 1,500 active duty lawyers in the AFJAGC (USAF, 2018c). They are an intelligent group requiring supervision, good leadership, and principled management. These 1,500 plus lawyers are an autonomous group of like-minded professionals who are accustomed to working independently, and who enjoy working issues and resolving them for commanders and civilian leaders.

The United States military has lawyers in every branch of its individual services-Army, Air Force, Marine Corps, Navy, Coast Guard. Each of these service branches manage, utilize, and train its lawyers in similar fashion. All of them assign various tasks, cases, and assignments in very similar legal settings. Not only are military lawyers trained the same, but each of them rely on the same case law and military traditions to get the job done. Also, senior lawyers in each branch manage subordinates using similar military training modules and processes. Arguably, there are some differences in management styles as seen from the subordinates' perspective.

\section{Power and Influence}

Inevitably, today everything in management deals with power and influence (Bass, 1999; Elias, 2008; French \& Raven, 1959), whether it is leading a military unit on the battlefield or leading lawyers in the AFJAGC, or managing a group of employees. Leadership, by its nature, is about human interaction and getting followers to act on behalf of an individual or an organization, in furtherance of that organization's goals and objectives (Elias, 2008; French \& Raven, 1959). The question remains which model (or 
management/leadership system) is best suited to manage/influence/exert power over lawyers, so they accomplish the organization's (Air Force) goals. How can the Air Force influence via some sort of power mechanism, minimizing friction, and get lawyers to want to do what is right for their employer (the Air Force and the AFJAGC)?

\section{Leadership in General}

There are various types of management/leadership styles that play a part in the interplay between leaders (senior Air Force lawyers) and followers (subordinate lawyers). We concentrate on three leadership styles: transactional (Cowsill \& Grint, 2008, p. 190; Jing \& Avery, 2008, p. 71); transformational (Dvir, Eden, Avolio, \& Shamir, 2002; Bass, 1985, as cited in Jing \& Avery, 2008); and servant-leader (Mayer, Bardes, \& Piccolo, 2008; Sendjaya, Sarros, \& Santora, 2008; Whetstone, 2002), since they are the most widely used in military circles.

\section{Military Leadership}

From a traditional military standpoint, military leadership has a long history and includes large amounts of mature theory (Edmondson \& McManus, 2007 and (Campbell, 2009; Guiliani, 2002)). Military leadership, in general, has historically been associated with transactional leadership. This type of leadership is based on a process by which a leader focuses on exchanges between him and followers, based on each other's needs and interests (Bass, 1999, p. 10; Jing \& Avery, 2008, p. 71). Based on French and Raven's (1959) power-interaction model, including five sources of power (reward, coercive, legitimate, referent, expert), the military has traditionally taken advantage of the reward, coercive, legitimate, and expert power in times past.

It has only been recently that there has been a shift to a more "referent" power angle to the use of power in the military, and in the Air Force specifically. This has also been due to the shift in civilian organizations (Elias, 2008). One of the main aspects of the military is its function. Traditionally, the military has unique characteristics that call for specific types of leadership, depending on the circumstances. They include the specific service's roles, culture, and people. The fact that the military is unquestionably traditional is undisputed. It consists of clear power delineations across hierarchical levels and clear guidance on how leaders and followers are supposed to interact. Power arrangements have a long history of tradition, and there are clear structures that define power for all within the system. Codes of behavior control in the everyday work environment and at every level in the military organization (Wong, Bliese, \& McGurk, 2003). This type of system calls for transactional type relationships between leader and follower.

There have also been other changes that affected traditional military operations, thus affecting military leadership in general. World affairs have changed. With the end of the Cold War; Persian Gulf Wars I and II; Kosovo; the war in Iraq; and now even the war in Afghanistan, military culture has evolved and changed. This, along with continuous deployments (Air Expeditionary Forces and even among Judge Advocates [lawyers]) (Hagar, 1920), has produced additional leadership challenges. Despite high-tech aspects of war, military leadership is still a human endeavor. It makes military leadership dependent on what leaders and follower do, believe, and act upon (Wong, et al., p. 660).

Culturally, military leadership is developed through formal education (i.e. Air Force Squadron Officer's School (USAF, 2018e), Air Command and Staff College (USAF, 2018a), Air War College (USAF, 2018b)), operational assignments (i.e. wartime assignments to the Area of Responsibility), and self-development (i.e. advanced degrees, other educational opportunities). Even though many of its members fit into any one of these categories at any given time in their military careers, military leadership is emphasized for leader development, whether it is officer or enlisted. What must always be remembered from a military leadership standpoint is that despite the military's hierarchical bureaucracy, the ultimate responsibility is to the American people. Given this charter, military leadership must follow the premise that it exists to serve the people and protect them against all enemies foreign and domestic. Thus, leadership style and behaviors of leaders become key from the military institution standpoint and to the people who rely upon them. Therefore, an institution that is involved in keeping the nation safe must 
continuously work to ensure that it's members (military members) give their "attention, time, energy, and commitment" (Wong, et al.,) to the nation. It is for these reasons that transformational and servant-leader leadership styles are the new leadership paradigms of the 21 st century.

This is also consistent with the new changes in current world markets and the new leader/followerchanges in the world's marketplaces, leader-follower interaction, as well as in politics, government, and culture. The airman, soldier, sailor, and marine of yesteryear, who was once seen as conservative, conforming, and institutionalized in his military service of choice, has evolved into one more educated, independent, motivated to challenge authority, plus cynical. This, in turn, has produced individualistictype military personnel, causing military leaders to adjust to military member expectations like never before. Military organizations have changed their managerial policies in order to accommodate this shift and now tread cautiously. They continuously chase after military members' wants, needs, and desires, in order to accomplish military goals and objectives (Bass, 1999; Gutman, 2000; Mitchell, 1998).

\section{Squadron Officer's School (SOS)}

Squadron Officer's School is also known as Primary Developmental Education (PDE) or SOS (USAF, 2018e). Here, Air Force officers (usually Captains) get their first taste of military leadership training. This course runs approximately six to eight weeks at Maxwell Air Force Base, Alabama, and it is also available by correspondence or seminar at most Air Force bases. It involves learning basic leadership principles in classes that include all career fields and officers from military bases throughout the world. The classes are intensive and require top reading and writing skills. Various projects include management principles at the squadron and unit level. Even though this course is helpful, it does not include leadership training for lawyers specifically. Most Air Force lawyers come directly from civilian life as opposed to the various commissioning sources such as Air Force Reserve Officer Training Corps (AFROTC) (USAF, 2018g), Officer Training School (OTS) (USAF, 2018d), or the United States Air Force Academy (USAFA) (USAFA, 2009). Since they have no prior military training, what is needed is a specific curriculum directed toward lawyers, given that they are specialists with duties in advisory roles to commanders.

\section{Air Command and Staff College (ACSC)}

Air Commend and Staff College is an Intermediate Developmental Education (IDE) and involves a one-year residency course at Maxwell Air Force Base, Alabama (USAF, 2018a). It is a course reserved for Majors at the intermediate level of management in their careers. Each year, approximately eight Air Force lawyers attend in residence. They are usually promoted to Lieutenant Colonel after completing this course in residence. The course is also available by correspondence or seminar at the local Air Force base. Even though the selection for the in-residence course is very competitive, it still involves various aspects of politics and current job. Thus, if an officer at the major's rank is in the right job at the right time, he has a better chance of attending the in-residence course. This course is geared toward midmanagement Air Force leaders, usually at the squadron or about-to-be squadron commander level. Again, this course offers very little in terms of specialty courses or models for Air Force lawyers. The courses in the curriculum are geared primarily towards the average squadron commander (i.e. pilots) in the Air Force, not the commander's legal advisor.

\section{Air War College (AWC)}

Air War College or Senior Developmental Education (SDE) is reserved usually for Lieutenant Colonels who have been selected and are among the top leaders in the Air Force (USAF, 2018b). Every year, approximately two to four Air Force lawyers are competitively selected to attend the in residence program at Maxwell Air Force Base, Alabama. This AWC course is also available by correspondence or by seminar at various bases. The course is reserved for the elite of the Lieutenant Colonel ranks, who are destined to become Colonels. This course is intended to educate future senior Air Force leaders on strategic matters. A large part of their curriculum includes long-term leadership training, but again, nothing specifically for lawyers. The closest this course gets in terms of leading lawyers is to include an 
article in one of its textbooks that involved The Judge Advocate General (general officer who served until 2004) in misconduct of fraternization, concentrating primarily on military justice and the Uniform Code of Military Justice (Fiscus, 2007). What is needed is a model for training senior Air Force lawyers in the servant/advisor role to commanders and military personnel in general.

\section{Air Force Leadership}

Since the Air Force has only existed in its present form since 1947 as a separate service, research into leadership models will necessarily draw from general military history (USAF, 2018f). The management model I develop will be a combination of that same mature theory but applied to the 21 st century AFJAGC. In order to understand Air Force leadership, one has to look to specific historical Air Force documents pertaining management or leadership training. In the Air Force, lawyers follow a textbook curriculum (Allison-Ceruti, et al., 2005), but there are very few follow-up courses or training modules that truly develop future lawyer leaders. Some of the factors that do contribute to the types of leadership needed to manage lawyers include changes in military culture, technology, individual needs, and ideology (Taylor Jr, 1977; Wren \& Dulewicz, 2005). As a result, traditional management models involving transactional leader behaviors have not worked in the past and will not work in the 21st century military or for the new 21st century military follower/subordinate (Bass, 1999; Cowsill \& Grint, 2008; Jing \& Avery, 2008). This, however, does not mean that all elements of transactional leadership behaviors are not usable. Some may carry over to a new management model.

\section{Leading Professionals}

The literature on the leadership of professionals is quite diverse, and includes such topics as motivation and job specific factors that play into keeping professionals in a firm or keeping them happy in their specific jobs (Jae Yoon, Jin Nam, \& Myung Un, 2008; Kotterman, 2006; Lakshman, 2006). Other articles mention theoretical concepts (Clancy \& Tata, 2005; Cowsill \& Grint, 2008; Lazarus, 2008) on how to distinguish between working professionals and professionals who manage other professionals, and the dilemmas professionals face when managing "their own." For example, doctors and nurses who manage other doctors and nurses usually have to shed themselves of the day-to-day duties they performed before managing their peers (Pepper, 2003; Stanley, 2006). However, there is no current management model for lawyers, particularly Air Force lawyers. While other professions' writers have published various theoretical, empirical, and practitioner articles, none of them point to a management style that is best suited for Air Force lawyers. Some articles describe what type of leaders are needed, but do not elaborate on a workable model that is applicable across the board for Air Force lawyers.

\section{Servant-Leader}

Servant-leader leadership (Hannay, 2008; Waddell, 2006) is a type of leadership style popularized by Robert K. Greenleaf in 1977 (Greenleaf, 2008). It is very applicable to the AFJAGC, since lawyers in the military have a dual role in that they are servants of the state (country) and its citizens; they are also servants of their primary clients - commanders. As such, Air Force lawyers, as public servants "are driven to serve first" (Hannay, p. 2), and are primarily motivated to help others (p. 3). Thus, the servantleader model of leadership and serving as a lawyer in the Air Force, go hand in hand. But, as of yet, there is no literature applying the servant leadership model to the AFJAGC or Air Force lawyers in general.

\section{Law Practitioner}

Finally, the literature is full of practitioner articles that touch on how law firm partners can develop skill sets and characteristics; how to manage a small law firm; how to operate within law firm budgets; how to manage from a partner perspective; and how to cut law firm costs. However, these literature only mentions briefly, and does not go in depth regarding what it would take to lead and manage military lawyers in the long run (Anonymous, 2005; Augsdorfer, 2008; Heffes, 2005). The practitioner literature on managing lawyers helps but needs to go deeper into the theory of lawyer management and leading professionals in general, particularly when it comes to military lawyers and their unique service practice. 


\section{Future Studies}

Potential future studies may include investigating the best management/leadership for Air Force lawyers, given the various new-employee (subordinate lawyers) factors of the 21 st century. A research goal can include finding out subordinate lawyers' perceptions of their lawyer managers' managerial styles, and what they think about these styles. More specifically, the goal can be to know how these different styles make them feel and how they act at work as a result.

Answering all these questions will ultimately solidify how to create a leadership model that is useful and easy to apply Air Force-wide. It will ultimately help determine if the present Air Force lawyer management processes are sufficient or lacking. Future studies in this area will aid in identifying management/leadership gaps by mid-level management or senior Air Force lawyer leaders who manage other lawyers. Ultimately, these types of future studies apply directly to a leader-model that employee perceptions of manager leadership styles are the most important factor in how to manage lawyers. This is consistent with the literature on leadership, Air Force management principles, management of professionals, the servant-leader model, and lawyer-practitioner practices.

\section{REFERENCES}

Allison-Ceruti, M. M., Cothrel, T. J., Hollingsworth, T. K., Norton, L. G., Wells, B. C., Austin-Smith, C. A., et al. (2005). I Lead! Developing JAG Corps Leaders. Retrieved from https://www.aflsa.jag.af.mil/ILead/.

Anonymous. (2005). What qualities make partners/leaders stand out from all the rest? Law Office Management \& Administration Report, 5(11), 5-6.

Augsdorfer, P. (2008). Managing the unmanageable. Research Technology Management, 51(4), 41-47.

Bass, B. M. (1999). Two decades of research and development in transformational leadership. European Journal of Work \& Organizational Psychology, 8(1), 9-32.

Campbell, D. (2009). Joker One: A Marine Platoon's Story of Courage, Leadership, and Brotherhood. New York, NY: The Random House Publishing Group.

Clancy, M., \& Tata, J. (2005). A global perspective on balancing work and family. International Journal of Management, 22(2), 234-241.

Cowsill, R., \& Grint, K. (2008). Leadership, task and relationship: Orpheus, Prometheus and Janus. Human Resource Management Journal, 18(2), 188-195.

Creswell, J. W. (2007). Qualitative Inquiry and Research Design. Thousand Oaks, CA: SAGE Publications, Inc.

Creswell, J. W. (2009). Research Design, Qualitative, Quantitative, and Mixed Methods Approaches (3rd ed.). Thousand Oaks, CA: SAGE Publications, Inc.

Dvir, T., Eden, D., Avolio, B. J., \& Shamir, B. (2002). Impact of transformational leadership on follower development and performance: A field experiment. Academy of Management Journal, 45(4), 735-744.

Edmondson, A. C., \& McManus, S. E. (2007). Methodological fit in management field research. Academy of Management Review, 32(4), 1155-1179.

Elias, S. (2008). Fifty years of influence in the workplace. Journal of Management History, 14(3), 267.

Fiscus, T. J. (2007). Thomas J. Fiscus, 14th Judge Advocate General, United States Air Force. 2007, from http://www.thomasjfiscus.net

French, J. R. P., \& Raven, B. (1959). The bases of social power. Originally printed in Studies in Social Power, Dorwin Cartwright, ed., 1959, pp. 150-165. Copyright 1959, Institute for Social Research. Printed in Classics of Organizational Behavior, 3rd Ed., Waveland Press, Inc., (2001), by Walter E. Natemeyer and J. Timothy McMahon, pp. 253-267(1959), 150-165.

Glatthorn, A. A., \& Joyner, R. L. (2005). Writing the Winning Thesis or Dissertation: A Step By Step Guide. Thousand Oaks, CA: Corwin Press.

Greenleaf, R. K. (2008). The Robert K. Greenleaf Center, Inc. The Robert K. Greenleaf Center, Inc. Retrieved 2010, from http://www.greenleaf.org/ 
Guiliani, R. W. (2002). Leadership. New York, NY: Talk Miramax Books.

Gutman, S. (2000). The Kinder, Gentler Military: Can America's Gender-Neutral Fighting Force Still Win Wars? Scribner, NY: Simon and Schuster.

Hagar, G. H. (1920). The Judge Advocate General's Department in the American Expeditionary Forces. California Law Review, 8(5), 300.

Hannay, M. (2008). The cross-cultural leader: The application of servant leadership theory in the international context. Journal of International Business and Cultural Studies (December 8, 2008), 5-7.

Heffes, E. M. (2005). Follow these leaders: Thoughts and views from Jim Collins. Financial Executive, 21(3), 20-23.

Jae Yoon, C., Jin Nam, C., \& Myung Un, K. (2008). Turnover of highly educated R\&D professionals: The role of pre-entry cognitive style, work values and career orientation. Journal of Occupational \& Organizational Psychology, 81(2), 299-317.

Jing, F. F., \& Avery, G. C. (2008). Missing links in understanding the relationship between leadership and organizational performance. International Business and Economics Research Journal, 7(May 2008), 67-78.

Kotterman, J. (2006). Leadership versus management: What's the Difference? Journal for Quality \& Participation, 29(2), 13-17.

Lakshman, C. (2006). A theory of leadership for quality: Lessons from TQM for leadership theory. Total Quality Management \& Business Excellence, 17(1), 41-60.

Lazarus, A. (2008). Adopting the CEO Model-Why physician executives should not be required to practice medicine. Physician Executive, 34(4), 24-26.

Maxwell, J. A. (2005). Qualitative Research Design: An Interactive Approach (2nd ed. Vol. 41). Thousand Oaks, CA: Sage Publications, Inc.

Mayer, D. M., Bardes, M., \& Piccolo, R. F. (2008). Do servant-leaders help satisfy follower needs? An organizational justice perspective. European Journal of Work \& Organizational Psychology, 17(2), 180-197.

Mitchell, B. (1998). Women in the Military: Flirting with Disaster. Washington D.C.: Regnery Publishing.

Pepper, A. (2003). Leading professionals: A science, a philosophy and a way of working. Journal of Change Management, 3(4), 349.

Sendjaya, S., Sarros, J. C., \& Santora, J. C. (2008). Defining and measuring servant leadership behaviour in organizations. Journal of Management Studies, 45(2), 402-424.

Stanley, D. (2006). Role conflict: leaders and managers. Nursing Management - UK, 13(5), 31-37.

Taylor Jr, C. W. J. (1977). Military professionals in changing times. Public Administration Review, 37(6), 633.

USAF. (2018a). Air Command and Staff College. Retrieved 2018, from Air University (Department of the Air Force) https://www.airuniversity.af.mil/ACSC/

USAF. (2018b). Air War College. Retrieved 2018, from Air University (Department of the Air Force) http://www.au.af.mil/au/awc/

USAF. (2018c). The Judge Advocate General's Corps. Retrieved 2018, from United States Department of Defense https://www.afjag.af.mil/

USAF. (2018d). Officer Training School. Retrieved 2018, from Air University (Department of the Air Force) https://www.airforce.com/education/military-training/ots

USAF. (2018e). Squadron Officer's School. Retrieved 2018, from Air University (Department of the Air Force) https://www.airuniversity.af.mil/SOS/

USAF. (2018f). United States Air Force. Retrieved 2018, from Department of the Air Force https://www.airforce.com/

USAF. (2018g). United States Air Force Reserve Officer Training Corps (AFROTC). Retrieved 2018, from Air University (Department of the Air Force) https://www.afrotc.com/

USAFA. (2009). United States Air Force Academy. Retrieved from http://www.usafa.af.mil/ 
Waddell, J. T. (2006). Servant Leadership. Paper presented at the Servant Leadership Roundtable. Retrieved from http://www.regent.edu/acad/global/publications/sl_proceedings/2006/waddell.pdf Whetstone, J. T. (2002). Personalism and moral leadership: the servant leader with a transforming vision. Business Ethics: A European Review, 11(4), 385-392.

Wong, L., Bliese, P., \& McGurk, D. (2003). Military leadership: A context specific review. The Leadership Quarterly, 14(2003), 657-692.

Wren, J., \& Dulewicz, V. (2005). Leader competencies, activities and successful change in the Royal Air Force. Journal of Change Management, 5(3), 295-309. 